The Cercle des Évolués of Brazzaville pleaded for a profound study of all African custom, pour en dégager le bien-fondé; if a custom is good, leave it alone; if not, modify it; but it advocated integration by means of assimilation in stages. On the other hand, M. Fily Dabo Sissoko, Chief of Niamba, A.O.F., argued strongly against assimilation and in favour of adaptation (the term he preferred to 'association'): he concluded: Let the Black remain black; let the White try all appropriate means of allowing the Black to develop on his own lines. The decision of the Conference appears to lean towards the former view. It was aware that the great mass of Africans remain faithful to their customary institutions; but also that there is an élite which is drawn towards a French way of life. The problem is to find the best way of ensuring the development of the masses towards French civilization and at the same time to give the élite every chance to show their capacity for administration. This is what the Conference recommended: 'Les institutions politiques traditionnelles doivent être maintenues non comme fin en soi mais en tant que mode permettant à la vie municipale et régionale de s'exprimer dès à présent avec le maximum de vigueur. L'Administration doit suivre et contrôler le fonctionnement de ces institutions, de façon à diriger leur évolution vers l'accession rapide des indigènes à la responsabilité politique.' It recommended that administrators should give personal attention to questions of marriage with the object of directing customs towards the liberty and dignity of women. As for polygamy -ce fleau de l'Afrique-the Administration must fight it with every means at its disposal. Every tribunal before which these family cases are brought should be presided over by a European official; in other civil and in commercial affairs native judges should for the present administer the customary law. A penal code for the whole of Africa is advocated. Education must reach the masses; a school should be opened in every village where fifty pupils are available as soon as the necessary teachers are trained; and girls should share equally with boys in the instruction. As for the school-language: 'L'enseignement doit être donné en langue française, l'emploi pédagogique des dialectes locaux parlés étant absolument interdit, aussi bien dans les écoles privées que dans les écoles publiques.' On this point, as M. Pleven has said, the Conference showed a tendency nettement assimilatrice, revealing its ambition that the natives in French Africa should evolve by stages into African Frenchmen.

The Conference recommended that a maximum delay of five years be allowed to re-establish the liberty of labour which the needs of war infringed. And to give labour an honourable place it was recommended that there be instituted an obligatory service of one year 'pour les indigènes de 20 à $2 \mathrm{I}$ ans reconnus aptes et qui n'auraient pas été pris dans la première portion du contingent militaire'. The men should be employed solely upon public works; and any man should be exempt who could prove that he had worked for a private employer eighteen months. Pensions should be assured to all native workers after is or 20 years of labour.

The Conference dealt with other matters which we cannot here refer to.

\title{
Political Developments in the Anglo-Egyptian Sudan
}

IN a lecture delivered at Makerere College (printed in The Bulletin of the Uganda Society, December 1944) Sir Douglas Newbold reviewed the steps which have been taken towards self-government in the Sudan, particularly in the six northern provinces with a population of 41 millions, mostly Arab-speaking and Muslim. In view of the chaos found by the new government when it came into being after the battle of Omdurman the period of twenty years from 1899 to 1919 was necessarily a period of direct rule, though even then a beginning was made in recreating the tribal system and there was some devolution to native authorities. A more definite policy of devolution followed the close of the first world war. It was soon found that native authorities could not rest on a basis of pure tribalism, or on the powers of the chiefs, but must be territorial on a local basis. In the last seven years there has been a development into something like the local government which obtains in civilized countries. 
'We have been anxious,' said Sir Douglas, 'and so have educated Sudanese, that native administration should not remain static and patriarchal or become fossilized. It must move with the times, cope with modern needs, be acceptable to educated natives (African or Arab), not resting only on traditions and privilege but on legal powers and popular consent.' Local government must be up to date, honest, and efficient: it is the best school or laboratory of self-government. Native authorities had their traditional powers regulated and extended by legislation in 1937. About that time a number of rural native authorities were given independent budgets ranging from $£ 5,000$ to $£ 30,000$ per annum, of which roughly half the revenue was allotted to local expenditure. At the beginning of this war a good measure of local government was in operation in the fields of administration, finance and justice; but as yet there was no real or formal association of educated Sudanese with the Central Government except in the so-called 'dilution policy', which is the policy of substituting Sudanese for British, Egyptian, and Syrian officials: a steady gradual process which was begun in I93 I. In Division II of the staff the cadre of Sudanese officials amounts now to about 75 per cent.; and in Division I, which includes doctors, education officers, district judges, and engineers, there are now over fifty Sudanese. During the first years of the war all energies were directed of necessity into military channels. The critical years of 1940 and 1941 put a great strain on the local Sudanese authorities; and, said Sir Douglas, 'they stood up to it splendidly', giving proof how valuable efficient local government is in a crisis. In September 1942, when all danger had passed away, Sir Douglas submitted a memorandum to the Governor-General's Executive Council, making proposals for closer association of Sudanese with government. These provided for (1) an extension of Town Councils with executive powers and independent budgets; (2) a Provincial Council system for the six northern provinces; (3) a Central Sudanese Advisory Council for the whole northern Sudan; (4) increased use of Sudanese on government committees; ( $s$ ) review and speeding up of 'dilution' of British officials by Sudanese; (6) appointment of a Public Relations Officer for liaison with the educated Sudanese. All these proposals were approved. There are now ten Town Councils, and twenty rural local governments with their own budgets, totalling together nearly half a million pounds sterling. By the end of 1943 six Provincial Councils were set up or planned, the members being all Sudanese except for a few foreign merchants. The first sessions of the Northern Sudan Council were held in May 1944: it consists of three members elected by each Provincial Council, two by the Chamber of Commerce, and eight nominated by the Governor-General, who is president of the Council. 'A preponderance of delegates are from the countryside, with a strong leaven of more highly educated Sudanese.' Of these various measures, Sir Douglas felt that the most important is the development of native administrations into a more democratic and rational form of local government. 'It is most important that native administration should not get fossilized nor be afraid of change and criticism.' All these councils, courts, and treasuries are only the machinery. 'The basis of local government is men and women, public-spirited men and women, and not only public-spirited chiefs and councillors, but public-spirited citizens, educated and uneducated, peasants who grow crops and raise livestock, school teachers, shop-keepers and the rest.' 'There is no real self-government possible without a community feeling among all citizens of a locality or territory. "The keywords are education and participation by the great body of the people.' This mears more representative councils, more co-operative societies in agriculture and commerce, more support by the people for schools and hospitals, more interest in research and especially in social science.

The reconstituted Gordon Memorial College at Khartum will eventually, it is hoped, attain the full status of a university granting its own fully recognized degrees. Now as a University College it will grant its own diplomas. The stage has thus been fully set for the 
training of Sudanese students for all departments of the professional life of their country. This will allow for increased 'dilution'.

These are all wonderful developments in a land which counts its modern history from only forty-five years ago. We can only regret that Sir Douglas Newbold, who died in March as the result of an accident, did not live to watch the progress which he did so much to promote and foster.

\section{Planning in Northern Rhodesia}

According to the tentative views of Mr. C. F. Clay, the Adviser on Development, which were submitted to the government of Northern Rhodesia last February, both Europeans and Africans will have their parts to play in the future. Some of the proposals needed further examination, but with regard to others the government expressed general agreement in April and undertook to apply for the necessary grants from the Colonial Development and Welfare Fund. This acceptance applies in particular to the plans for Development Centres and to these we now limit our exposition. Leaving aside the Kaonde-Lunda province in the north-west, five centres are to be chosen for their suitability to serve zones in which social and ecological conditions are relatively uniform. At each Centre there will be a roo-bed hospital; a normal school; a combined agricultural and veterinary research station, which will later serve as a stock-farm for multiplication and distribution of improved crops and stock; a model community centre with Native Treasury, Native Court and central village school; a butcher's shop and various craftsmen's shops; and an area of land embracing not less than a group of six family holdings will be laid out in accordance with the latest views of the Centre concerning planned development of village lands. The buildings to be erected will be of the simplest type. The staff at each Centre will comprise six Europeans, including (2) medical, agricultural, veterinary, and education officers and a senior District Officer in charge; there will also be a subordinate European staff of three nursing sisters and health, agricultural and livestock inspectors. At a later stage technical instructors are to be appointed to experiment in the development of village industries-in the Barotse centre such an instructor will be appointed from the first: it is not clear why the other Centres will have to wait. Associated with each Centre there are to be four or five native authority areas under the control of the team at the Centre; the nature of this 'control' is not stated, but they will be demonstration areas in which accelerated development will be stimulated. Without attempting a rigid definition of the matters with which the Centres will be concerned the plan specifies housing, sanitation, diet, child welfare and maternity work, mass education, development of a system of local government in step with the social and economic development that is being planned, and local marketing systems. The Centres are to be lighthouses radiating the beams of civilization over the whole territory. At each Centre training will be given to African medical orderlies for village dispensaries, village schoolmasters and rural assistants. The last-named will receive training in all the practical aspects of a sound and healthy rural life, the design and construction of improved housing, \&c. These men will be posted to local centres in teams of three at the conclusion of their training; in ten years it is hoped that 1,570 such centres will be fully staffed, one centre for each thousand of the African population.

Who, it may be asked, is to see that the work of the trained Africans at the local centres is carried on efficiently? Apparently the necessary inspection and supervision will not be done by the officers at the Centres. A number of secondary Development Teams, directed by Provincial Teams of high-grade staff, will be established for this purpose. Joint planning by the Provincial Teams will be directed to such features of development as rural water-supplies. Special projects, such as anti-tsetse schemes, demanding specialist knowledge, will remain in the hands of the technical departments. 